\title{
Effect of Sample Dimensions on Static Bending Test
}

\author{
Luciano Junqueira Costa ${ }^{1}$ (1) 0000-0003-4582-9210 \\ Camila Batista da Silva Lopes ${ }^{1}$ (1) 0000-0003-0753-5094 \\ Matheus Fernandes de Carvalho Reis ${ }^{1}$ () 0000-0002-3357-0945 \\ Marcos Oliveira de Paula ${ }^{1}$ (D) 0000-0002-7815-7396 \\ Clarissa Gusmão Figueiró ${ }^{1}$ (1) 0000-0002-8572-554X \\ Lucas de Freitas Fialho ${ }^{1}$ (1) 0000-0001-8002-9214 \\ Jéssica Dornelas Soares ${ }^{1}$ (i) 0000-0003-2734-3591
}

\begin{abstract}
This study aimed to evaluate the static bending strength $\left(\mathrm{f}_{\mathrm{M}}\right)$ and modulus of elasticity (MOE) to static bending values of Eucalyptus grandis samples produced in different dimensions. It intended to identify samples that present similar mechanical properties to those recommended by other technical standards and those obtained according to NBR 7190. The samples were made in agreement with the dimensions of the following standards: IPT, AFNOR B51-016, ASTM D143, CEN-EN 408, COPANT 555, and NBR 7190. The strength was significantly reduced with the increase of the sample dimensions. The MOE was significantly influenced by the samples size with the values showing a parabolic trend. The samples produced according to COPANT $555(5 \times 5 \times 75 \mathrm{~cm})$ presented resistance values similar to the values obtained following NBR 7190 specifications, whereas for the MOE, the samples proposed according to the IPT presented the closest values of Brazilian technical standards (NBR 7190).
\end{abstract}

Keywords: mechanical testing, modulus of elasticity, mechanical strength, Eucalyptus grandis.

\section{INTRODUCTION AND OBJECTIVES}

Wood is one of the main materials used in construction. This material has the characteristic of being renewable and having a wide variety of properties between species that give it various applications. As wood is a heterogeneous material in terms of anatomical structure and chemical composition, the knowledge of its mechanical properties is fundamental and serves as a tool for understanding its quality, appropriate use, and the dimensions of structural parts (Bertolini et al., 2012; Lahr et al., 2017).

Among the mechanical properties of wood, the resistance to static bending is one of the most important characteristics for structural use, and this test is usually used to determine the modulus of elasticity. Generally, this property is used in beam sizing and as a criterion for comparing species (Stangerlin et al., 2010). The structural applications in which the wood undergoes bending efforts are diverse, such as in floor supports, beams of bridges and roofs, among many others.
In Brazil, the standard for mechanical characterization of wood is NBR 7190 (ABNT, 1997). The resistance and modulus of elasticity to the static bending of the wood are determined by means of tests carried out on specimens with a prismatic dimension, using a square cross section with a width of $5 \mathrm{~cm}$ and length of $115 \mathrm{~cm}$ in the parallel direction to the fibers. These pieces should be free from defects and obtained from a batch considered to be homogeneous. However, the presence of defects in the wood are the result of intrinsic characteristics of the species or growing conditions of the tree, such as the presence of knots, resin pockets, holes caused by insects, or other types of wood damages, which result in deviations in the directions of the fibers or make the production of samples in accordance with NBR7190 standards difficult (Hossein et al., 2011; Koman et al., 2013; Müller et al., 2014; Vidaurre et al., 2013). Other factors, such as the volume of material available for the development of the mechanical tests and the capacity of the equipment, are limiting in the decision making in relation to the size of the specimens.

${ }^{1}$ Universidade Federal de Viçosa (UFV), Viçosa, MG, Brasil 
Regarding the dimensions of the specimens, some standards allow for the reduction of both the cross section and the length of the specimens for the static bending test. The American Society for Testing and Materials (ASTM), through ASTM D143, suggests using a smaller sample cross section from $5 \times 5 \mathrm{~cm}$ to $2.5 \times 2.5 \mathrm{~cm}$, as well as from $76 \mathrm{~cm}$ to $41 \mathrm{~cm}$ for the static bending test (ASTM, 2000). However, the Brazilian standard NBR 7190 (ABNT, 1997) does not allow for the reduction of the dimensions of the test specimens for the static flexural strength test, which both makes it difficult to make specimens into logs with small diameters and result in defects in the wood that reduce the useful area of the wood.

It is essential to determine the appropriate size of the specimen for mechanical testing, as the mechanical properties of the material can be significantly influenced by the dimensions of the specimen tested (Büyüksarı et al., 2017). In addition, the effect of sample size on both the static bending strength and the modulus of elasticity of the wood may vary from species to species (Melo et al., 2015).

The objective of this study was to evaluate the resistance and modulus of elasticity to the static flexion of Eucalyptus grandis specimens, manufactured in different dimensions in order to identify which specimens recommended by other technical standards present values of these properties similar to those observed for NBR 7190 .

\section{MATERIALS AND METHODS}

Three trees of Eucalyptus grandis, aged 33 years old, were collected in Viçosa, MG. The wood material were prepared in central planks, from which boards were removed, as recommended by NBR 7190 (ABNT, 1997). A defect-free test sample was removed from each board. The specimens were prepared and framed in six size classes according to the guidelines of the technical standards, according to Table 1.

Table 1. Dimensions (radial, tangential, and length in centimeters) of the samples used in the static bending strength $\left(f_{M}\right)$ and modulus of elasticity (MOE) determination test of Eucalyptus grandis wood.

\begin{tabular}{cccc} 
Classes & $\begin{array}{c}\text { Technical } \\
\text { standard }\end{array}$ & $\mathbf{f}_{\mathrm{M}}$ & MOE \\
\hline 1 & IPT (1956) & $(2 \times 2 \times 30)$ & $(2 \times 2 \times 30)$ \\
2 & $\begin{array}{c}\text { AFNOR B51-016 } \\
(1987)\end{array}$ & $(2 \times 2 \times 36)$ & $(2 \times 2 \times 36)$ \\
\hline 3 & $\begin{array}{c}\text { ASTM D143 } \\
(2000)\end{array}$ & $(2.5 \times 2.5 \times 41)$ & $(2.5 \times 2.5 \times 41)$ \\
\hline 4 & $\begin{array}{c}\text { CEN-EN } 408 \\
(1995)\end{array}$ & $(3 \times 3 \times 57)$ & $(3 \times 3 \times 57)$ \\
\hline 5 & $\begin{array}{c}\text { COPANT } 555 \\
(1973)\end{array}$ & $(5 \times 5 \times 75)$ & $(5 \times 5 \times 75)$ \\
\hline $6-$ & NBR 7190 (1997) & $(5 \times 5 \times 115)$ & $(5 \times 5 \times 115)$ \\
\hline
\end{tabular}

Twelve test specimens were prepared for each dimensional class. For each test sample, the strength and modulus of elasticity were determined by static bending.

The tests were carried out on a universal test machine with a load capacity of 10,000 kgf. The calculation of the modulus of elasticity was determined by an extensometer with an accuracy of $0.001 \mathrm{~mm}$. At the time of the mechanical tests, the specimens had a humidity of approximately $15 \%$, so the test results were corrected to the standard moisture of $12 \%$ as proposed by NBR 7190 .

In order to be standardized, the tests with the different test specimens were performed in accordance with the Brazilian standard NBR 7190. This was performed in a static system, in which the specimen are two supports with a central concentrated load and a constant loading speed.

The results were submitted to analysis of variance (Anova), applying the $\mathrm{F}$ test at a significance level of $5 \%$. Then, the means were compared to the control by the Dunnett test, adopting the same level of significance.

\section{RESULTS AND DISCUSSION}

The mean values of static bending strength as a function of the dimensions of the samples are shown in Figure 1. There was no significant effect of the specimen strength on the mechanical strength of the wood, except for specimen class 1 (IPT, 1956). The value found for the test specimens of class 1 was $20 \%$ higher than that observed for the control, which overestimates the value of the resistance. Thus, its use is not interesting for the determination of the resistance to static bending.

In the analysis of the Dunnett test when using the resistance to static flexion obtained in test specimens of dimensions recommended by NBR 7190 as a control (ABNT, 1997), it was statistically verified that test specimen classes $2,3,4$, and 5 presented no significant difference in relation to the control. The test specimens of class 5 (Copant, 1973), which have dimensions of $5 \times 5 \times 75 \mathrm{~cm}$, were those that presented values of static bending strength closer to those observed for the specimens in the dimensions recommended by the Brazilian standard.

The size of the specimen significantly influences the mechanical properties of the wood, especially in its resistance. Smaller specimens have greater static bending strength when compared with larger samples (Schlotzhauer et al., 2015). The resistance of the wood is linked to properties such as density, moisture, initial/late wood ratio, chemical composition, among other factors that vary both radially and longitudinally. According to Schneeweiß \& Felber (2013) and Melo et al. (2015), larger test specimens and, consequently, larger volumes result in greater heterogeneity of the wood properties, 
which contributes to its lower mechanical resistance when compared to smaller specimens.

The relationship between the length of the specimen and the cross section (L/a) results in variations in the mechanical strength of the wood. The static bending strength is affected mainly by the variation in the length of the test specimens. It should be noted that the longest sample lengths for the same cross section (higher L/a ratio) results in lower mechanical resistance of the wood to static bending (Schlotzhauer et al., 2015).

The values of modulus of elasticity to the static bending of the wood in relation to the dimension of the specimens presented a statistical difference (Figure 2).

According to Figure 2, class 4 (CEN, 2010) of test specimens differed statistically from the control for the values of modulus of elasticity, being about $19 \%$ greater than the specimen of standard NBR 7190. An increase of the modulus of elasticity can be observed in the test specimens of classes 1 through 4 , whereas specimens with dimensions above this class tend to decrease in values.

The modulus of elasticity was significantly influenced by the samples size with the values showing a parabolic trend, which is similar to that found by Melo et al. (2015). These authors, evaluating the effect of five dimensions of specimens for the determination of the modulus of elasticity of tropical species, found that the increase of the specimen dimensions results in an initial increase in modulus of elasticity values. This was followed by a reduction in values, as the dimensions of the specimens increase mainly in the cross section.

Figure 3 shows the trend of the variation coefficient for the results of resistance and modulus of elasticity to the static flexion for the different size classes of the specimens.

By the coefficient of variation, it is possible to observe the variability of the results of the tests for each one of the dimensions. The increase, mainly in the cross section of the specimen up to section $3 \times 3 \mathrm{~cm}$, resulted in greater variation in the results of the test, both for the modulus of elasticity and for the strength. The opposite result was observed for the specimens with a larger cross section, such as $5 \times 5 \mathrm{~cm}$, which tended to reduce the variation in results.

Test specimens with a $5 \times 5 \mathrm{~cm}$ cross section have a greater number of growth rings, such that the mechanical strength is less influenced by the difference between the initial and late wood and also resulting in greater representativeness of the material during sampling. However, samples with greater lengths and cross sections, despite having a greater representativity of the material, can be influenced by both the radial and longitudinal variation of the wood properties, such as density and humidity (Melo et al., 2015; Torres et al., 2016).
In order to perform the static bending test, it is essential that the moisture presents a uniform distribution throughout the specimen, since the variation of humidity can result in occasional changes in the resistance of the bending wood and, consequently, modify the results (Stangerlin et al., 2010; Vivian et al., 2010). This fact may explain the reduction of the values of both strength and modulus of elasticity for specimens with a cross section of $5 \times 5 \mathrm{~cm}$.

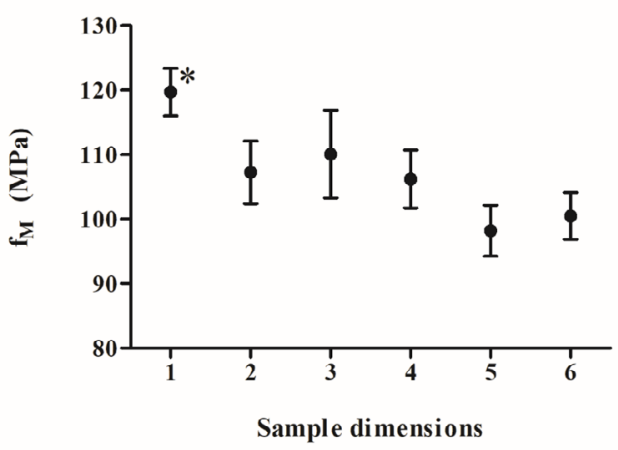

Figure 1. Mean value of static bending strength $\left(f_{M}\right)$ for samples with different dimensions.

* Significant difference at the significance level of $5 \%$ by the Dunnett test.

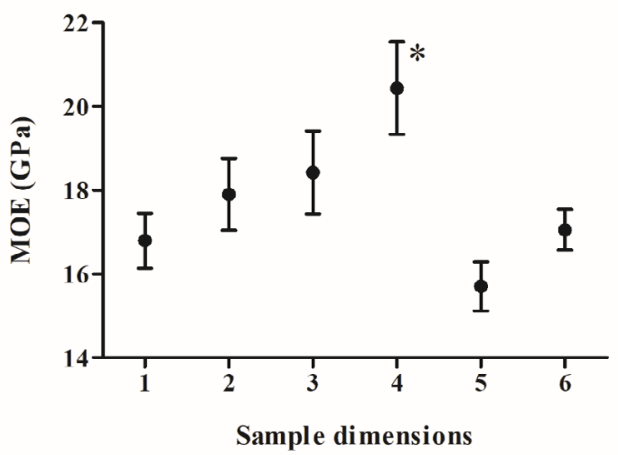

Figure 2. Mean value of modulus of elasticity (MOE) obtained in the static bending test for samples with different dimensions.

* Significant difference at the significance level of $5 \%$ by the Dunnett test.

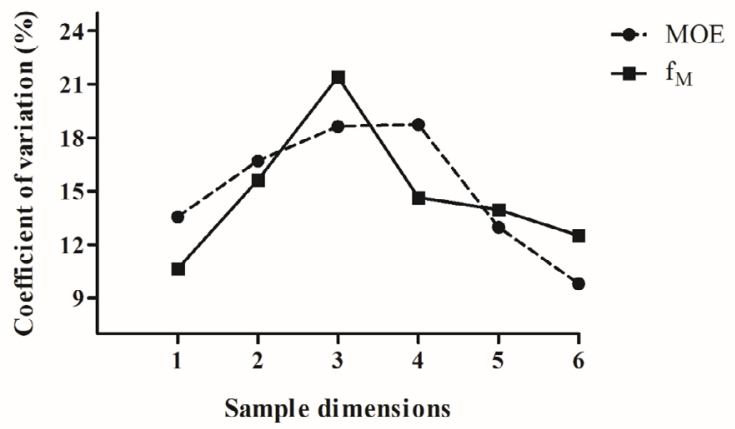

Figure 3. Coefficient of variation of strength $\left(f_{M}\right)$ and modulus of elasticity (MOE) as a function of sample dimensions. 


\section{CONCLUSIONS}

In determination of the mechanical resistance to static flexion, class 5 specimens (Copant, 1973) presented the closest values to those found by the standard NBR 7190 . For the modulus of elasticity, class 1 specimens (IPT, 1956) were those that presented the closest values to the observed for the test body established by NBR 7190 .

If a reduction is necessary because of defects in the wood, the volume of available material and the capacity of the equipment is important. For the static bending test, the $5 \times 5 \times 75 \mathrm{~cm}$ specimen is recommended, while for the modulus of elasticity, the recommended specimen is the $2 \times 2 \times 30 \mathrm{~cm}$ one.

\section{ACKNOWLEDGEMENTS}

The authors thank the Coordenação de Aperfeiçoamento de Pessoal de Nível Superior (Capes), the Conselho Nacional de Desenvolvimento Científico e Tecnológico $(\mathrm{CNPq})$ and the Fundação de Amparo à Pesquisa do Estado de Minas Gerais (Fapemig) for the financial support. Also, the Laboratório de Painéis e Energia da Madeira (Lapem) and the Universidade Federal de Viçosa for helping in this work's development.

\section{SUBMISSION STATUS}

Received: 4 Oct. 2017

Accepted: 31 July 2018

Associate editor: Divino Eterno Teixeira

0000-0001-5450-1095

\section{CORRESPONDENCE TO}

\section{Luciano Junqueira Costa}

Universidade Federal de Viçosa (UFV), Av. Peter Henry Rolfs, s/n, CEP 36570-900, Viçosa, MG, Brasil

e-mail: junqueira.lct@gmail.com

\section{REFERENCES}

American Society for Testing and Materials - ASTM. ASTM D143: standard methods testing: small clear specimens of timber. Philadelphia: ASTM; 2000.

Associação Brasileira de Normas Técnicas - ABNT. NBR 7190: projetos de estruturas de madeira. Rio de Janeiro: ABNT; 1997.

Bertolini MS, Silva DAL, Souza AM, Calil Neto C, Lahr FAR. Influência do comprimento de corpos-de-prova na obtenção do módulo de elasticidade Ec0. Floresta e Ambiente 2012; 19(2): 179183. 10.4322/floram.2012.021

Büyüksarı Ü, As N, Dündar T, Korkmaz O. Micro-mechanical properties of oak wood and comparison with standard-sized samples. Maderas: Ciencia y Tecnologia 2017; 19(4): 481-494. 10.4067/S0718-221X2017005000801
Comisión Panamericana de Normas Técnicas - Copant. COPANT 555: método de ensayo de flexión estática. Buenos Aires: Copant; 1973.

European Committee for Standardization - CEN. CEN-EN 408: timber structures: structural timber and glued laminated timber: determination of some physical and mechanical properties. Brussels: CEN; 2010.

Hossein MA, Shahverdi M, Roohnia M. The effect of wood knot as a defect on modulus of elasticity (MOE) and damping correlation. Notulae Scientia Biologicae 2011; 3(3): 145-149. $10.15835 / \mathrm{nsb} 336119$

Instituto de Pesquisas Tecnológicas - IPT. IPT 56: madeiras nacionais: tabela de resultados de ensaios físicos e mecânicos. São Paulo: IPT; 1956.

Koman S, Feher S, Abraham J, Taschner R. Effect of knots on the bending strength and the modulus of elasticity of wood. Wood Research 2013; 58(4): 617- 626.

Lahr FAR, Nogueira MCJA, Araujo VA, Vasconcelos JS, Christoforo AL. Physical-mechanical characterization of Eucalyptus urophylla wood. Engenharia Agrícola 2017; 37(5): 900-906. 10.1590/18094430-eng.agric.v37n5p900-906/2017

L'Association Française de Normalisation - AFNOR. AFNOR B51016: bois: méthodes d'essais: essai de choc ou flexion statique. Paris: AFNOR; 1987.

Melo JE, Souza MR, Costa AF. Influência das dimensões dos corpos de prova e da velocidade de ensaio na resistência à flexão estática de três espécies de madeiras tropicais. Ciência Florestal 2015; 25(2): 415-424. 10.5902/1980509818461

Müller BV, Rocha MP, Cunha AB, Klitzke RJ, Nicoletti MF. Avaliação das principais propriedades físicas e mecânicas da madeira de Eucalyptus benthamii Maiden et Cambage. Floresta e Ambiente 2014; 21(4): 535-542. 10.1590/2179-8087.050413

Schlotzhauer P, Nelis PA, Bollmus S, Gellerich A, Militz H, Seim W. Effect of size and geometry on strength values and MOE of selected hardwood species. Wood Material Science \& Engineering 2015; 12(3): 149-157. 10.1080/17480272.2015.1073175

Schneeweiß G, Felber S. Review on the bending strength of wood and influencing factors. American Journal of Materials Science 2013; 3(3): 41-45. 10.5923.j.materials.20130303.01

Stangerlin DM, Melo RR, Gatto DA, Cademartori PHG. Propriedades de flexão estática da madeira de Carya illinoinensis em duas condições de umidade. Ciência da Madeira 2010; 1(2): 70-79. 10.12953/2177-6830.v01n02a06

Torres PMA, Paes JB, Nascimento JWB, Brito FMS. Caracterização físico-mecânica da madeira jovem de Eucalyptus camaldulensis para aplicação na arquitetura rural. Floresta Ambiente 2016; 23(1): 109-117. 10.1590/2179-8087.016012

Vidaurre GB, Lombardi LR, Nutto L, França FJN, Oliveira JTS, Arantes MDC. Propriedades da madeira de reação. Floresta e Ambiente 2013; 20(1): 26-37. 10.4322/floram.2012.041

Vivian MA, Modes KS, Beltrame R, Morais WC, Souza JT, Machado WG et al. Resistência da madeira de canafístula (Peltophorum dubium (Spreng.) Taub.) ao PSF e a umidade de equilíbrio. Ciência da Madeira 2010; 1(1): 12-25. 10.12953/21776830.v01n01a02 